\title{
An Assessment of Sustainability across the Campus
}

Jack T. Tessier ${ }^{1, *}$, Nana-Yaw Andoh ${ }^{2}$, Kristin DeForest ${ }^{3}$, Matthew W. Juba ${ }^{4}$, Akira Odani $^{5}$, John J. Padovani ${ }^{4}$, Elizabeth F. Sova ${ }^{6}$, \& Lisa M. Tessier ${ }^{1}$

${ }^{1}$ Liberal Arts and Sciences, SUNY Delhi, 454 Delhi Dr., Delhi, NY 13753, United States

${ }^{2}$ Applied Sciences and Building Technologies, SUNY Delhi, 454 Delhi Dr., Delhi, NY 13753, United States

${ }^{3}$ Resnick Learning Center, SUNY Delhi, 454 Delhi Dr., Delhi, NY 13753, United States

${ }^{4}$ Residence Life, SUNY Delhi, 454 Delhi Dr., Delhi, NY 13753, United States

${ }^{5}$ Business and Hospitality, SUNY Delhi, 454 Delhi Dr., Delhi, NY 13753, United States

${ }^{6}$ O’Connor Center for Community Engagement, SUNY Delhi, 454 Delhi Dr., Delhi, NY 13753, United States

*Corresponding author: Tel: 1-607-746-4483 E-mail: tessiejt@delhi.edu

Received: September 23, 2013 Accepted: November 11, 2013 Published: November 25, 2013

doi:10.5296/ije.v5i4.4318 URL: http://dx.doi.org/10.5296/ije.v5i4.4318

\begin{abstract}
Across the curriculum approaches have been used successfully with a variety of topics to demonstrate the importance of skills and ideas across topical areas. Sustainability is a logical candidate for an across the curriculum approach because the concept itself spans disciplines. We sought to implement sustainability across the campus to extend the idea of topical breadth. Sustainability was integrated across four disciplines and three non-curricular areas with control groups to assess the impact of the approach on students' understanding of the concept and their view of its importance. Based in responses to a voluntary survey, students experiencing the treatment courses scored significantly better in their understanding of sustainability than control students. These approaches were less successful in helping students to see the relevance of sustainability to their courses and careers. These results demonstrate that sustainability can be effectively integrated across the campus, but more work needs to be done to promote application of and student caring about sustainability.
\end{abstract}

Keywords: architecture; business; community service; economy; environment; learning services; residence halls; society 


\section{Introduction}

A powerful way to develop skills and ways of thinking is to integrate them into courses across disciplines. This approach is called "across the curriculum" and has been applied to numerous topics. These include critical thinking (King, 1995), information technology (Fedorowicz, Gelinas, Usoff, \& Hachey, 2004), physical activity (Donnelly et al., 2009), debate (Bellon, 2000), mathematics (Cerrito, 1996; Kleiman, 1991), and writing (Fulwiler, 1984). The success of these disciplines in the across the curriculum approach begs the question of what other topics could be successfully integrated among courses.

Sustainability is a concept that will be important to the persistence of humans on planet Earth. Sustainability means to be able to do something in perpetuity. The only way to do that is to make sure that an activity meets the three tenets of sustainability (Goodland, 1995). First, the activity must support the economy to provide jobs and economic success. Second, the activity must maintain a happy and healthy society, including fair treatment, high quality of life, and freedom. Third, the activity must manage ecosystems such that resources are not extracted faster than they can be replenished and any resource extraction must conserve the ecosystems for the myriad services they provide, such as water filtration, pollinators, flood abatement, carbon uptake, climate control, and aesthetics. Bringing sustainability to fruition is a very challenging task because of the multiple hurdles that have been installed by modern society, including excessive consumer demand and institutional legacies (Fischer et al., 2012). The slowest and most important changes that need to take place to develop a sustainable society involve changes in personal beliefs and values (Fischer et al., 2012), making it important for students to understand sustainability and appreciate its relevance to all topics in their lives.

With sustainability growing as a discipline and across disciplines (Clark, 2007), approaches have been made to incorporate it across the curriculum (Lidgren, Rodhe, \& Huisingh, 2006; Lozano, 2006). While it has been used across the curriculum in some areas (Christensen, Peirce, Hartman, Hoffman, \& Carrier 2007; Dyllick \& Hockerts, 2002; Roome, 2005, Sammalisto \& Lindhqvist, 2008; Shrivastava, 1995), significant social and economic hurdles have kept it from becoming a common program of study (Scott and Gough, 2006). Additionally, data are needed to detail the efficacy of integrating sustainability across the curriculum (Rusinko, 2010). Finally, Moore (2005) recommends expanding sustainability to more than just a curricular issue, and spread the changes into every sector of the academic institution.

This study follows up on the need to assess sustainability across the curriculum efforts and the recommendation to expand the concept to other areas of campus. Our objective was to integrate the concept of sustainability into courses from different disciplines and into non-curricular areas of campus, and to quantify the impact of these experiences on students' knowledge of sustainability and their view of its importance. 


\section{Methods}

Conduct of this study was approved by SUNY Delhi's Institutional Review Board before the onset of data collection. All involved faculty and staff received a one hour training session on the meaning and importance of sustainability, and how it could be infused into all areas of campus. This session included a Power Point presentation and discussion of the topics. Due to curricular limitations, we used Rusinko's (2010) option I for integrating sustainability across the campus (at the level of courses rather than programs). We embedded the concept into four courses and three non-curricular areas of campus (Table 1) as recommended by Moore (2005). This approach allowed us to compare the influence of the treatment courses (ones in which sustainability was purposefully built into the course content as it related to the topic of the course) to that of control courses (ones in which sustainability was not included) on students' understanding of sustainability and its importance, as well as document the influence of non-curricular activities on those same criteria.

Table 1: Summary of courses and areas of campus involved in a sustainability across the campus project at SUNY Delhi, Delhi, NY USA

\begin{tabular}{|c|c|c|c|}
\hline $\begin{array}{l}\text { Course or Area of } \\
\text { Campus }\end{array}$ & Description & $\begin{array}{l}\text { Sustainability } \\
\text { Components }\end{array}$ & Control \\
\hline $\begin{array}{l}\text { ARCH } 135 \\
\text { Architectural Design } \\
\text { Fundamentals }\end{array}$ & $\begin{array}{l}\text { Fundamentals of 2- } \\
\text { and 3-dimensional } \\
\text { design }\end{array}$ & $\begin{array}{l}\text { Three tenets of } \\
\text { sustainability } \\
\text { researched and } \\
\text { incorporated into } \\
\text { final architectural } \\
\text { design project }\end{array}$ & $\begin{array}{l}\text { Separate section of } \\
\text { ARCH } 135\end{array}$ \\
\hline $\begin{array}{l}\text { BIOL } 110 \\
\text { Environmental Issues } \\
\text { and Sustainability }\end{array}$ & $\begin{array}{l}\text { Exploration of } \\
\text { current } \\
\text { environmental issues } \\
\text { and their solutions }\end{array}$ & $\begin{array}{l}\text { Three tenets of } \\
\text { sustainability as core } \\
\text { concept of six, } \\
\text { required reports }\end{array}$ & $\begin{array}{l}\text { BIOL } 220 \text { Human } \\
\text { Anatomy and } \\
\text { Physiology I - } \\
\text { Introductory biology } \\
\text { course related to the } \\
\text { human body }\end{array}$ \\
\hline $\begin{array}{l}\text { BUSI } 100 \\
\text { Introduction to } \\
\text { Business }\end{array}$ & $\begin{array}{l}\text { Introduction to } \\
\text { current business in } \\
\text { America }\end{array}$ & $\begin{array}{l}\text { Emphasized the triple } \\
\text { bottom line (People, } \\
\text { Planet, Profit) } \\
\text { throughout the course }\end{array}$ & $\begin{array}{l}\text { Separate section of } \\
\text { BUSI } 100\end{array}$ \\
\hline $\begin{array}{l}\text { HUMN } 242 \text { History } \\
\text { of World and Western } \\
\text { Architecture II }\end{array}$ & $\begin{array}{l}\text { Factors that shaped } \\
\text { architecture from } \\
\text { Renaissance to } \\
\text { present }\end{array}$ & $\begin{array}{l}\text { Fieldtrips to } \\
\text { green-design } \\
\text { buildings followed } \\
\text { by discussion and } \\
\text { written reports } \\
\text { focusing on the three } \\
\text { tenets of } \\
\text { sustainability. }\end{array}$ & $\begin{array}{l}\text { ARTS } 300 \text { Art and } \\
\text { Health - Art course } \\
\text { relating images of the } \\
\text { health field to the } \\
\text { development of art }\end{array}$ \\
\hline
\end{tabular}




\begin{tabular}{|c|c|c|c|}
\hline $\begin{array}{l}\text { Resnick Learning } \\
\text { Center }\end{array}$ & $\begin{array}{l}\text { Tutoring, EOP, } \\
\text { advising, and career } \\
\text { services }\end{array}$ & $\begin{array}{l}\text { Informing students of } \\
\text { the importance of the } \\
\text { Resnick Learning } \\
\text { Center's shift to } \\
\text { electronic from paper } \\
\text { forms }\end{array}$ & $\begin{array}{l}\text { Students who did not } \\
\text { participate in } \\
\text { Resnick Learning } \\
\text { Center activities }\end{array}$ \\
\hline $\begin{array}{l}\text { O'Connor Center for } \\
\text { Community } \\
\text { Engagement }\end{array}$ & $\begin{array}{l}\text { Organization of } \\
\text { community service } \\
\text { and service learning } \\
\text { events }\end{array}$ & $\begin{array}{l}\text { Participants were } \\
\text { informed of the value } \\
\text { of their community } \\
\text { service as it related to } \\
\text { the three tenets of } \\
\text { sustainability }\end{array}$ & $\begin{array}{l}\text { Students who did not } \\
\text { participate in } \\
\text { O'Connor Center } \\
\text { activities }\end{array}$ \\
\hline Residence Life & $\begin{array}{l}\text { Residence hall } \\
\text { programming }\end{array}$ & $\begin{array}{l}\text { Each Resident } \\
\text { Assistant conducted a } \\
\text { residence hall } \\
\text { program about } \\
\text { sustainability at least } \\
\text { once during the year }\end{array}$ & $\begin{array}{l}\text { Students who did not } \\
\text { participate in } \\
\text { Residence Life } \\
\text { programming }\end{array}$ \\
\hline
\end{tabular}

In Architectural Design Fundamentals, students were asked to design a small pavilion at the end of the semester. The location of the pavilion needed to take into account passive solar energy for cooling and heating. In addition, students had to research a minimum of three sustainable materials for the design of the pavilion. The material research included the sustainable qualities of the product, how the product was manufactured, from where the material was be delivered to the project site, and how the use of the material benefited the end users (people), the environment (planet), and the manufacturers (profit).

In Environmental Issues and Sustainability, students were required to write six, two page reports. The topics of these reports ranged widely, and students had choices about which topics to choose. Examples included tropical deforestation, food, energy policy, toxic pollution, immigration, diapers, and ecological footprint. Each report required the students to detail how their ideas related to the three tenets of sustainability. Additionally, students completed a project at the end of the semester, which required them to make an aspect of our state sustainable. Examples of aspects included water, food, security, recreation, and housing.

In Introduction to Business, when working with Capitalism and Free Market Economy, the class emphasized the critical importance of triple bottom line, i.e., economic responsibility of businesses making profit balanced with responsibilities of enhancing benefits to people (employees, customers, and communities) and the planet (environmental protection). The triple bottom line is often summarized into a phrase of 3Ps of business (profit, people, and planet). In addition, this introductory business class focused on the integrity of leadership, ethics, and corporate social responsibility. One chapter was devoted to the subject, while the same theme was repeated throughout the semester. 
In History of World and Western Architecture II, sustainability was discussed as it applies to contemporary architecture in the last three weeks of the semester. In classroom discussion, sustainable designs were defined as those that attempt to integrate economic, social and environmental factors so that the system/product creates minimal disruption to the environment, enhances the quality of life, and is ideally self-supporting. A jig-saw, sustainability-themed fieldtrip was then implemented. Students self-selected a fieldtrip destination that tied to sustainability from three options: a LEED certified building on a nearby college campus, a sustainability-themed satellite campus for a nearby college, or a newly built green-design for the SUNY Delhi daycare center. Students judged the building they visited by the three tenets of sustainability. They scored the building along a scale of Platinum (the best score), Gold, Silver, and Certified (meaning there was room for some improvement) and explained their score for each of the three criteria. Finally, the entire class met back to share their experiences, images, and evaluations of each site for these three criteria. In this way, the jig-saw was closed as students that attended only one site were able to learn from their peers about the other two destinations.

The Resnick Learning Center made many efforts to reduce paper use, which reduced costs, made access to documents more convenient for staff and students, and limited natural resource use. These efforts included moving assessment portfolios to an electronic database, resume and cover letter critiques moved to email instead of paper copies, shifting Transfer Services information to internet versions instead of paper flyers, and moving general files to electronic formats from their former paper versions. The economic, social, and environmental benefits of these changes were pointed out to students as they used the services.

The O'Connor Center for Community Engagement reduced paper use, traded disposable gloves for gloves that are washed and reused, and reused plastic grocery bags for litter pickup instead of store bought bags. Students submitted hours of service to the Center via email instead of paper copies. During the study, a destructive hurricane caused massive flooding of the campus's neighboring towns and villages. Students volunteered to help with the cleanup efforts, and the Center provided them with good work gloves instead of the usual disposable type. The gloves were gathered at the end of each day and washed. Trips back and forth to these devastated places allowed for discussion of issues related to sustainability, flood abatement, global warming, and responsibility. Later on in the year, students collected litter and cigarette butts in Delhi. Instead of the traditional garbage bags used in the past, used grocery bags were utilized. That task was a concrete lesson in reusing, and respecting our environment that students pass on to their friends and neighbors. Additionally, the Center worked with the campus auxiliary services to promote the recycling of bottles and cans on campus. Funds from those efforts went to make a campus community garden that provided some herbs and tomatoes to meals served on college grounds.

Residence Life offered building programming based on the principles of sustainability. The program included building-wide recycling of paper, glass, plastic types $1 \& 2$, and household metals. In addition, students were educated on sustainability topics such as energy and natural resource usage/conservation, recycling and waste management, and renewable energy through programming, bulletin boards and contests. Students were encouraged to implement the 
principles of sustainability while living in the residence halls and to maintain the life-long practice of sustainability. Each Resident Assistant (one per floor) was required to implement at least one program during the year related to the sustainability. These included topics such as recycling, littering, and water conservation. The second annual Residence Life Earth Week hosted 14 events educating students on sustainability. Two hundred thirty students attended the events that 15 RAs planned. Thirteen Environmental Representatives were hired to coordinate the collection of clothes, educational supplies, food, and other housewares at the end of each semester for donation to local charities.

Students voluntarily completed identical surveys (Table 2) at the beginning and end of the semester in all treatment and control courses. A consistent survey was used to assess student learning among all courses (as opposed to in class projects) to be able to compare the results among courses and use the data from the surveys from control courses to assess the influence of the non-curricular areas on students understanding of and appreciation for sustainability. The survey provided data about students' knowledge of the three tenets of sustainability and how much they felt sustainability was relevant to the course and their careers. The survey was useful in addressing multiple levels of learning. Students' knowledge of the three tenets of sustainability relates to lower level learning, defined by Bloom, Engelhart, Furst, Hill, and Krathwohl (1956) as Recall and by Fink (2003) as Foundational Knowledge. Both Bloom et al. (1956) and Fink (2003) would refer to students' appreciation of the importance of sustainability to the course topics as Application, because students are seeing how sustainability is applied to the various disciplines and activities. Students' perspective on the importance of sustainability to their careers is high level learning, because it asks them to evaluate whether or not sustainability is an important concept for their life's pursuits. Bloom et al. (1956) would define this level as Evaluation and Fink (2003) would define it as Caring.

Table 2: Survey given to students in a sustainability across the campus project at SUNY Delhi, Delhi, NY USA.

Date: Last Four Digits of Your 800 Number:

This survey, which should take less than five minutes to complete, is designed to assess the effectiveness of your experience at Delhi to help you understand the concept of sustainability (our species' ability to live indefinitely on Earth) to your future. Your completion of this survey is voluntary and will not affect your course grade.

1. In what class are you completing this survey?

2. Do you regularly use the Resnick Learning Center (circle one)?

$$
\text { Yes No }
$$

3. Do you regularly take part in O'Connor Center for Community Engagement activities (circle one)?

Yes No


4. Do you regularly take part in Residence Life programs related to sustainability (circle one)?

$$
\text { Yes No }
$$

5. What are the three tenets (or components) of sustainability?

6. How relevant is sustainability to the topic of this course (circle one)?

Very Important Important Neutral Unimportant Very Unimportant

7. How likely are you to consider sustainability in your job setting and career (circle one)?

Very Likely Likely NeutralUnlikely Very Unlikely

Surveys were scored in the following way. Students earned one point for each tenet of sustainability that they successfully identified. Relevance of sustainability to the course responses were scored 1 for Very Important down to 5 for Very Unimportant. Similarly, relevance of sustainability to the career responses were scored 1 for Very Likely down to 5 for Very Unlikely. We paired each student's pre- and post-semester surveys and quantified the change in the number of known tenets and their view of the relevance of sustainability to the course and their career. Finally, we compared the post-semester scores to our assessment goals of students knowing at least two tenets of sustainability, viewing sustainability as at least important to the course, and students being at least likely to consider sustainability in their career after their experiences in a course or non-curricular activities.

All statistical analyses were conducted with Minitab version 16 (Minitab, Inc., State College, PA USA). Statistical significance of differences was determined using a Type I error probability of $\alpha=0.05$. For data regarding courses, a t-test was used within each course pairing to compare each change score between the treatment and control course. For the non-curricular activities, a t-test was used to compare the change in the number of known tenets and the change in the student's perspective of the relevance of sustainability to their career between students who did (treatment) and did not (control) take part in two or more of the non-curricular areas. We ruled out students who participated in just one non-curricular area because one experience was unlikely to have an important impact on a student's thinking, particularly in comparison with a semester-long course.

\section{Results}

One hundred sixty eight surveys were voluntarily completed by students. These included 21 for ARCH 135 and 9 for its control section; 25 for BIOL 110 and 28 for its control class; 23 for BUSI 100 and 25 for its control section; and 23 for HUMN 242 and 14 for its control class.

The courses in which sustainability was integrated into the course content were consistently able to improve students' understanding of sustainability to a greater degree than did control courses (Table 3). Only in the Environmental Issues and Sustainability course did students 
increase in the perspective that sustainability was relevant to the course more than in the control course (Table 3). Students in treatment courses did not view sustainability as more relevant to their careers than students in control courses, although this difference approached significance in History of World and Western Architecture II. (Table 3).

Table 3: Effect of embedding sustainability into courses and non-curricular activities on students understanding of sustainability and their sense of its relevance to the course and their careers relative to controls at SUNY Delhi, Delhi, NY USA. T refers to treatment and C refers to control. Numbers in parentheses are standard errors. P values are based on a t-test. Results in bold are significantly different at $\alpha=0.10$.

\begin{tabular}{|c|c|c|c|}
\hline Course Name & $\begin{array}{l}\text { Mean Change } \\
\text { in \# Known } \\
\text { Tenets of } \\
\text { Sustainability } \\
\text { (Post-Pre) }\end{array}$ & $\begin{array}{l}\text { Mean Change in } \\
\text { Students' View of the } \\
\text { Relevance of } \\
\text { Sustainability to the } \\
\text { Course (Post-Pre; } \\
\text { Negative change } \\
\text { means increasing } \\
\text { relevance) }\end{array}$ & $\begin{array}{l}\text { Mean Change in } \\
\text { Students' View of the } \\
\text { Relevance of } \\
\text { Sustainability to } \\
\text { Their Career } \\
\text { (Post-Pre; Negative } \\
\text { change means } \\
\text { increasing relevance) }\end{array}$ \\
\hline ARCH 135 & T $0.524(0.16)$ & Т $0.04(0.31)$ & Т $0.38(0.26)$ \\
\hline Architectural Design & C -0.11 (0.20) & C $0.11(0.20)$ & C $0.33(0.24)$ \\
\hline Fundamentals & $\mathbf{P}=\mathbf{0 . 0 2 4}$ & $P=0.850$ & $P=0.907$ \\
\hline BIOL 110 & T $2.04(0.20)$ & T -0.64 (1.00) & $\mathrm{T}-0.04(0.26)$ \\
\hline Environmental Issues & C -0.13 (0.09) & C $0.31(1.04)$ & C $0.11(0.25)$ \\
\hline and Sustainability & $\mathbf{P}<0.0001$ & $\mathbf{P}=\mathbf{0 . 0 0 1}$ & $\mathrm{P}=0.685$ \\
\hline BUSI 100 Introduction & T $0.65(0.29)$ & Т $0.04(1.15)$ & Т $0.13(0.26)$ \\
\hline \multirow[t]{2}{*}{ to Business } & C -0.32 (0.15) & C $0.37(0.76)$ & C $-0.40(0.26)$ \\
\hline & $\mathbf{P}=\mathbf{0 . 0 0 5}$ & $\mathrm{P}=0.279$ & $\mathrm{P}=0.156$ \\
\hline HUMN 242 History of & T $1.78(0.39)$ & $\mathrm{T}-0.65(0.22)$ & $\mathrm{T}-0.35(0.15)$ \\
\hline World and Western & C -1.14 (0.39) & C $-0.17(0.42)$ & C $0.21(0.26)$ \\
\hline Architecture II & $\mathbf{P}<0.0001$ & $\mathrm{P}=0.325$ & $\mathrm{P}=0.075$ \\
\hline \multirow[t]{3}{*}{ Non-Curricular Areas } & $\mathrm{T}-0.08(0.12)$ & NA & Т $0.09(0.17)$ \\
\hline & C - $-0.60(0.24)$ & & C $0.55(0.18)$ \\
\hline & $P=0.069$ & & $P=0.077$ \\
\hline
\end{tabular}

While students who did not take a treatment course all knew fewer tenets of sustainability at the end of the semester than at the beginning of the semester, the difference in the number of tenets forgotten between students involved in two or more non-curricular activities and those 
who did not approached significance (Table 3). The view of the relevance of sustainability to a student's career decreased during the semester for all students who did not take a treatment course, but the difference in that perspective between students who were involved in two or more non-curricular activities and those who did not approached significance (Table 3).

Students met our assessment goals in some but not all areas. Students knew at least two of the tenets of sustainability at the end of the semester in two of the four courses, but not after participating in two or more of the non-curricular activities (Table 4). Students viewed sustainability as important or very important to two of the four courses (Table 4). Finally, students reported that they were likely or very likely to consider sustainability in their careers after experiences in three of the four courses and participating in two or more of the non-curricular activities (Table 4), although in the case of the non-curricular areas students reached this goal without increasing their view of the importance of sustainability to their careers during the semester (Table 3).

Table 4: Comparison of results to assessment goals for a sustainability across the campus project at SUNY Delhi, Delhi, NY USA. Numbers are means for the class or activity with standard errors in parentheses. Bold numbers indicate areas in which the assessment goal was met.

\begin{tabular}{|c|c|c|c|}
\hline Course or Activity & $\begin{array}{l}\text { Number of Tenets } \\
\text { Known (Goal of } \geq 2 \text { ) }\end{array}$ & $\begin{array}{l}\text { Students' View of } \\
\text { the Relevance of } \\
\text { Sustainability to } \\
\text { The Course } \\
\text { (Goal of } \leq 2 \text { ) }\end{array}$ & $\begin{array}{l}\text { Students' View of the } \\
\text { Relevance of } \\
\text { Sustainability to } \\
\text { Their Career (Goal } \\
\text { of } \leq 2 \text { ) }\end{array}$ \\
\hline $\begin{array}{l}\text { ARCH } 135 \\
\text { Architectural Design } \\
\text { Fundamentals }\end{array}$ & $0.60(0.15)$ & $2.00(0.17)$ & $1.92(0.18)$ \\
\hline $\begin{array}{l}\text { BIOL } 110 \\
\text { Environmental } \\
\text { Issues and } \\
\text { Sustainability }\end{array}$ & $2.28(0.20)$ & $1.32(0.17)$ & $1.96(0.19)$ \\
\hline $\begin{array}{l}\text { BUSI } 100 \\
\text { Introduction to } \\
\text { Business }\end{array}$ & $1.17(0.26)$ & $2.22(0.23)$ & $2.30(0.23)$ \\
\hline $\begin{array}{l}\text { HUMN } 242 \text { History } \\
\text { of World and } \\
\text { Western Architecture } \\
\text { II }\end{array}$ & $2.19(0.24)$ & $2.27(0.12)$ & $1.77(0.13)$ \\
\hline $\begin{array}{l}\text { Non-Curricular } \\
\text { Areas }\end{array}$ & $0.310(0.09)$ & NA & $2.00(0.19)$ \\
\hline
\end{tabular}




\section{Discussion}

Based on the results of this study, sustainability can be effectively integrated not only across the curriculum but also across the campus. Every course developed higher student capacities with sustainability than control groups (Table 3). This pattern approached significance for participation in two or more non-curricular activities, as well (Table 3). Students also met our assessment goal in the majority of conditions (Table 4). These results bolster the recommendation of Moore (2005) to implement sustainability concepts in every aspect of a campus. While our approach used Rusinko's (2010) most simple approach to integrating sustainability (at the level of courses rather than programs), we were still successful at increasing students' understanding of sustainability. This approach may be even more useful than the programmatic approach because a sustainability program would reach students who are already interested in sustainability, while our approach reached students who may have been less interested in sustainability to begin with but are still critical to the implementation of sustainable practices in our society (Fischer et al., 2012).

We were most effective at increasing students' understanding of the principles of sustainability, and less effective at helping students to see how sustainability was relevant to our courses and their careers (Table 3). This result speaks to a general trend in students to learn what they need to learn for a course without seeing the value of that content beyond the classroom despite its importance there (Gann, 2001). This pattern is further supported by the courses having a greater impact on conceptual understanding and relevance of sustainability than our non-curricular activities (Table 3). Students seem to struggle to put together connections between academic ideas and their real-world applications. The decrease in the number of known tenets and students perspective of the importance of sustainability among students who did not take a treatment class is disconcerting (Table 3), but may be attributable to an early semester sense of idealism and energy (Smith \& Weaver, 2006) compared to a late semester focus on just finishing up.

As an approach to integrating sustainability across the campus, we were generally not successful in helping students see the importance of the concept to their topics of study and their lives (Bouillion \& Gomez, 2001), although students reached the assessment goal in the majority of areas (Table 4). In revising our approaches to make them better in the future, we need to develop experiences (classroom activities, written work, projects, etc.) that help to make obvious ties between sustainability and our students' futures. Fink (2003) refers to these areas as Application and Caring. In Application, students make use of a concept with a real-world setting to help them better understand the concept (Fink, 2003). Caring means that the experience the students have with the concept is not merely an academic pursuit, but a realization of the importance of the concept to their lives that causes them to take the concept with them in their decision making (Fink, 2003). Personalizing the concept will be important to making the individual changes necessary to rebuild our society in a sustainable fashion (Fischer et al., 2012), and these are the areas in which we must focus our efforts. We are implementing changes to our courses to overcome this fact.

The great value of assessment is to isolate areas where improvement is warranted and 
possible (Airasian, 1996; Astin \& Antonio, 2012; Boud \& Falchikov, 2007). Our current efforts to improve this sustainability across the campus project include the following changes. In Architectural Design Fundamentals, the materials list is narrowed down to focus on sustainable materials and students see a presentation detailing how the tenets of sustainability apply to the built environment. The Environmental Issues and Sustainability course now includes a report specifically targeting students' careers and their impact on sustainability. In Introduction to Business, having discovered through a pre- and post- test results that the knowledge of critical concepts do not stay in students' memory for long, the instructor is repeating and revisiting the same themes much more often than before, sacrificing peripheral, non-core ideas and concepts. In History of World and Western Architecture II, students will critique one of their own design projects or their home using the tenets of sustainability. The Resnick Learning Center is developing posters that explain the tenets of sustainability, highlight the sustainable activities within the Center, and encourage students to do their best to help. The O'Connor Center for Community Engagement is targeting projects that are relevant to students' career interests and infusing more long-term service learning projects to provide a more meaningful experience to students. Residence Life has hired Sustainability Advocates who will educate residents about sustainability and sustainable practices in the residence halls throughout the semester along with participating in the End of Semester Donations Program for local charities.

\section{Conclusion}

Based on our results, we are confident that sustainability can be successfully infused across the campus, not just the curriculum. Across our courses and non-curricular areas we were able to develop improvements in students' understanding of sustainability and/or meet our assessment goals. We identified areas that will need improvement, notably helping students to connect sustainability to their lives and better framing non-curricular activities within the conceptual basis and importance of sustainability. In helping us to strengthen our efforts, this research serves as an excellent example of how assessment can improve educational practices. We encourage others to undertake similar endeavors and develop programs that work for their own institutions.

\section{Acknowledgement}

We thank Ben McGraw, Bret Meckel, and Mark Schneider for assisting with the development of the project and Hartwick College for hosting field trips for History of World and Western Architecture II. 


\section{References}

Airasian, P.W. (1996). Assessment in the Classroom. New York, NY, USA: McGraw Hill.

Astin, A.W., \& Antonio, A.L. (2012). Assessment for Excellence: The Philosophy and Practice of Assessment and Evaluation in Higher Education. Lanham, MD, USA: Roman \& Littlefield.

Bellon, J. (2000). A research-based justification for debate across the curriculum. Argumentation and Advocacy, 36(3), 161-175. Retrieved from http://www.argumentationandadvocacy.com/

Bloom, B.S., Engelhart, M.D., Furst, E.J., Hill, W.K., \& Krathwohl, D.R. (1956). Taxonomy of Educational Objectives: The Classification of Educational Goals: Handbook 1 Cognitive Domain. New York, NY, USA: David McKay Company, Inc.

Boud, D., \& Falchikov, N. (Eds.). (2007). Rethinking Assessment in Higher Education: Learning for the Longer Term. New York, NY, USA: Routledge.

Bouillion, L.M., \& Gomez, L.M. (2001). Connecting school and community with science learning: real world problems and school-community partnerships as contextual scaffolds. Journal of Research in Science Teaching, 38(8), 878-898. http://dx.doi.org/10.1002/tea.1037

Cerrito, P.B. (1996). Mathematics across the curriculum. College Teaching, 44(2), 48-51. http://dx.doi.org/10.1080/87567555.1996.9933426

Christensen, L.J., Peirce, E., Hartman, L.P., Hoffman, W.M., \& Carrier, J. (2007). Ethics, CSR, and sustainability education in the Financial Times top 50 global business schools: baseline data and future research directions. Journal of Business Ethics, 73(4), 347-368. http://dx.doi.org/10.1007/s10551-006-9211-5

Clark, W.C. (2007). Sustainability science: a room of its own. Proceedings of the National Academy of Sciences USA, 104(6), http://dx.doi.org/10.1073/pnas.0611291104

Donnelly, J.E., Greene, J.L., Gibson, C.A., Smith, B.K., Washburn, R.A., Sullivan, D.K., DuBose, K., Mayo, M.S., Schmelzle, K.H., Ryan, J.J., Jacobsen, D.J., \& Williams, S.L.K. (2009). Physical activity across the curriculum (PAAC): a randomized controlled trial to promote physical activity and diminish overweight and obesity in elementary school children. Preventive Medicine, 49(4), 336-341. http://dx.doi.org/10.1016/j.ypmed.2009.07.022

Dyllick T., \& Hockerts, K. (2002). Beyond the business case for corporate sustainability. Business Strategy and the Environment, 11(2), 130-141. http://dx.doi.org/10.1002/bse.323

Fedorowicz, J., Gelinas, Jr., U.J., Usoff, C., \& Hachey, G. (2004). Twelve tips for successfully integrating enterprise systems across the curriculum. Journal of Information 
Systems Education, 15(3), 235-244. Retrieved from http://jise.org/Volume15/15-3/Pdf/N15N3P235-Abs.pdf

Fink, L.D. (2003). Creating Significant Learning Experiences: An Integrated Approach to Designing College Courses. San Francisco, CA, USA: Jossey-Bass.

Fischer, J., Dyball, R., Fazey, I., Gross, C., Dovers, S., Ehrlich, P.R., Brulle, R.J., Christensen, C., \& Borden, R.J. (2012). Human behavior and sustainability. Frontiers in Ecology and the Environment, 10(3), 153-160. http://dx.doi.org/10.1890/110079

Fulwiler, T. (1984). How well does writing across the curriculum work? College English, 46(2), 113-125. http://dx.doi.org/10.2307/376857

Gann, D. (2001). Putting academic ideas into practice: technological progress and the absorptive capacity of construction organizations. Construction Management and Economics, 19(3), 321-330. http://dx.doi.org/10.1080/01446190010020480

Goodland, R. (1995). The concept of environmental sustainability. Annual Review of Ecology and Systematics, 26(1), 1-24. http://dx.doi.org/10.1146/annurev.es.26.110195.000245

King, A. (1995). Designing the instructional process to enhance critical thinking across the $\begin{array}{llll}\text { Curriculum. } & \text { Teaching } & \text { Psychology, } & \text { 22(1), }\end{array}$ http://dx.doi.org/10.1207/s15328023top2201_5

Kleiman, G.M. (1991). Mathematics across the curriculum. Educational Leadership, 49(2), 48-51. Retrieved from http://kennytucker.cmswiki.wikispaces.net/file/view/math+across + content+article.pdf/3 60762558/math\%20across\%20content\%20article.pdf

Lidgren, A., Rodhe, H., \& Huisingh, D. (2006). A systemic approach to incorporate sustainability into university courses and curricula. Journal of Cleaner Production, 14(9-11), 797-809. http://dx.doi.org/10.1016/j.jclepro.2005.12.011

Lozano, R. (2006). Incorporation and institutionalization of SD into universities: breaking through barriers to change. Journal of Cleaner Production, 14(9-11), 787-796. http://dx.doi.org/10.1016/j.jclepro.2005.12.010

Moore, J. (2005). Seven recommendations for creating sustainability education at the university level. International Journal of Sustainability in Higher Education, 6(4), 326-339. http://dx.doi.org/10.1108/14676370510623829

Roome, N. (2005). Teaching sustainability in a global MBA: insights from the ONeMBA. Business Strategy and the Environment, 14(3), 160-171. http://dx.doi.org/10.1002/bse.445

Rusinko, C.A. (2010). Integrating sustainability in higher education: a generic matrix. International Journal of Sustainability in Higher Education, 11(3), 250-259. http://dx.doi.org/10.1108/14676371011058541

Sammalisto, K., \& Lindhqvist, T. (2008). Integration of sustainability in higher education: a 
study with international perspectives. Innovation in Higher Education, 32(4), 221-233. http://dx.doi.org/10.1007/s10755-007-9052-x

Scott, W., \& Gough, S. (2006). Sustainable development within UK higher education: revealing tendencies and tensions. Journal of Geography in Higher Education, 30(2), 293-305. http://dx.doi.org/10.1080/03098260600717398

Shrivastava, P. (1995). The role of corporations in achieving ecological sustainability. Academy of Management Review, 20(4), 936-960. http://dx.doi.org/10.5465/AMR.1995.9512280026

Smith, J.K., \& Weaver, D.B. (2006). Capturing medical students' idealism. Annals of Family Medicine, 4(S1), S32-S37. http://dx.doi.org/10.1370/afm.543

\section{Copyright Disclaimer}

Copyright reserved by the author(s).

This article is an open-access article distributed under the terms and conditions of the Creative Commons Attribution license (http://creativecommons.org/licenses/by/3.0/). 